Piotr MOCEK

Radosław ZAMIAR

Robert JACHIMCZYK

Ryszard GOWARZEWSKI

Jerzy ŚWIĄDROWSKI

Iwona GIL

KrzysZtof STAŃCZYK

\title{
SELECTED ISSUES OF OPERATING 3 MW UNDERGROUND COAL GASIFICATION INSTALLATION
}

\section{WYBRANE ZAGADNIENIA EKSPLOATACJI INSTALACJI PODZIEMNEGO ZGAZOWANIA WĘGLA O MOCY TERMICZNEJ 3 MW*}

\begin{abstract}
Experiences of operating underground coal gasification installation (UCG) are discussed in the article. The gasification experiment was conducted in active Wieczorek coal mine. The assumed maximum gasification capacity of the installation was $600 \mathrm{~kg} / \mathrm{h}$ of coal, i.e. $3 \mathrm{MW}$ contained in enthalpy of gas. An integrated design process was applied in preparing equipment of the UCG installation. The result was long-lasting tests (over $1400 \mathrm{~h}$ ) of coal gasification process at near-atmospheric pressure. Gasification was conducted in a $5.4 \mathrm{~m}$ thick deposit with a mixture of: air and oxygen, air and $\mathrm{CO}_{2}$, air and water. Data on performance of a semi-industrial scale UCG installation were collected. The aim of the article is to present the process and selected experiences associated with operating the installation. External limitations influencing the gasification method, design of basic nodes and rules of running the process are described. The main problems encountered during the gasification process and UCG gas purification are presented.
\end{abstract}

Keywords: underground coal gasification, pilot installation, controlling process.

\begin{abstract}
Omówiono doświadczenia z eksploatacji urzadzeń podziemnego zgazowania węgla (PZW). Próbę zgazowania przeprowadzono w funkcjonującej Kopalni Węgla Kamiennego "Wieczorek". Projektowana wydajność zgazowania wynosiła $600 \mathrm{~kg} / \mathrm{h}$ węgla. Przektada się to na $3 \mathrm{MW}$ mocy termicznej zawartej w entalpii gazu. Przygotowując urządzenia instalacji PZW zastosowano zintegrowany cykl projektowania. Wynikiem byto przeprowadzenie dlugotrwatych (ponad 1400 h) badań procesu zgazowania węgla przy ciśnieniu zbliżonym do atmosferycznego. Zgazowanie prowadzono w złożu o średniej mią̇szości $5.4 \mathrm{~m}$ wykorzystując mieszaninę: powietrza i tlenu, powietrza i $\mathrm{CO}_{2}$ oraz powietrza i wody. Uzyskano informacje z funkcjonowania w skali póltechnicznej instalacji PZW. Celem publikacji jest przedstawienie procesu i wybranych doświadczeń z funkcjonowania tej instalacji. Opisano ograniczenia zewnętrzne wptywające na sposób rozwiązania technologii zgazowania, konstrukcje podstawowych węzłów i zasady prowadzenia procesu. Wskazane zostały główne problemy wystęujące w trakcie procesu zgazowania i oczyszczania gazu z PZW.
\end{abstract}

Stowa kluczowe: podziemne zgazowanie węgla, instalacja pilotowa, sterowanie procesem.

\section{Introduction}

The idea of underground coal gasification (UCG) is to supply gas reagent directly into the gasification area located in a coal seam $[4,7,20]$. The products of chemical conversion processes occurring there are: process gas, water, condensates containing hydrocarbons (tar substances), unreacted char, and thermally processed mineral substance of coal. Mixture containing $\mathrm{H}_{2}, \mathrm{CO}, \mathrm{CO}_{2}, \mathrm{~N}_{2}, \mathrm{H}_{2} \mathrm{~S}, \mathrm{CH}_{4}, \mathrm{C} 2+$, and water steam is exhausted from the georeactor. Solids (coke breeze from decomposing coal and thermal transformations of hydrocarbons, dust) also get into the gas pipeline. Some of the mineral matter of coal, biochar and condensates remain underground. UCG gas contains impurities, hence, depending on its application, it should be dedusted and desulfurized. Then its components should be condensed and undergo further conversion processes $[8,13,27]$. The operation depends on the requirements which process gas shall meet $[1,8,18,19,25]$.
Underground coal gasification installation differs greatly in its function from conventional gasification equipment. Industrial surface gasification installations, fed with coal, biomass or mixtures of waste; do not differ so much in their parameters, particularly availability, from typical equipment of energy sector and chemical industry [17, $21,24]$. Its elements are relatively less durable, especially the ones which are exposed to aggressive components of process gas. Surface gasification systems, where hot gas is fed into atmospheric pressure combustion chamber, do not have long sections connecting the gasification reactor with the furnace. As a result, the amount of condensing tar components is reduced. Integrated gasification combined cycle installations (IGCC), i.e. high pressure gasification installations, are not so easily available. It is so because of technologically demanding parameters of work from a reactor through a dust separator to a combustion turbine $[6,11,12,23]$. It also means relatively more often check-ups of the turbine and its system.

(*) Tekst artykułu w polskiej wersji językowej dostępny w elektronicznym wydaniu kwartalnika na stronie www.ein.org.pl 
Underground coal gasification installations, unlike other gasification systems, do not require building a conversion reactor. The process of injecting gasification agents, followed by exhausting and purifying the products, requires certain equipment. Its characteristic elements are: long sections of substrate and process gas pipelines, differentiated thermodynamic parameters in the georeactor, safety requirements, and technical and operational limitations $[13,14,15]$.

The factor which determines technicalities is the followed UCG technology. Gasification conducted in coal seams with mining operations or seams of high risk of UCG gas outflow [26, 29], requires maintaining near-atmospheric pressure in the gasification area. The produced gas has relatively low density. In its content dominate components for which equilibrium conditions of chemical conversion are characteristic for low pressure $(\mathrm{CO}, \mathrm{H} 2)$. Such UCG gas should be exhausted with large-diameter pipelines.

Integrated methods of coal gasification and "in situ" process gas conversion, such as CRIP method [22], to obtain high content of $\mathrm{CH}_{4}$ and $\mathrm{CO}_{2}$ in process products, enable maintaining pressure near hydrostatic pressure at the gasification depth in the reactor and a significant part of the gas transmission installation. Processes conducted at higher than hydrostatic pressure are limited by a risk of uncontrollable leak of gas and increased risk of polluting ground water with condensing components. High pressure installations require different solutions concerning both supply of substrates and exhausting products, purifying them and stabilizing UCG process [23]. High-pressure methods are more efficient at converting coal within a seam. They offer possibility of applying larger streams of water in gasification agent. In the case of the process much stricter technical regime is required [2].

Within the framework of project financed by the National Centre for Research and Development titled: "Development of coal gasification technology for highly efficient production of fuels and energy", an original pilot installation of underground coal gasification with air, air enriched with oxygen, and air mixed with water or $\mathrm{CO}_{2}$ was realised Its aim was trial exploitation of a coal seam with underground gasification method at a semi-industrial scale. Comparing with hitherto research in Poland, an increase in the scale of the project was significant. The tests were to obtain process data as well as balance and economic data which would enable designing a pilot - industrial scale installation. It was also important to acquire practical knowledge of running the process in conditions hitherto untested in Poland. Within the framework of conducted technical works and tests the following elements were prepared:

- new concept of purifying UCG gas,

- own method of controlling the installation,

- method of transmitting gas in long sections of a high-temperature and thermally compensated, insulated pipeline. As a result, significant part of condensation occurs on the surface.

The designed installation is particularly unique taking into consideration the fact it was designed to meet safety requirements of an active mine. It required devising right methods of gasification and monitoring workings around the georeactor.

The aim of the article is to present experiences of operating UCG installation at semi-industrial scale. The process was conducted in an active and operating coal mine, with low-pressure method. The external limitations which influence the way the installation was designed, design of basic nodes and rules of conducting the process are described. Main problems occurring when the installation was operating are described as they are important for further development of the method to produce energy.

\section{Assumptions of gasification process}

Underground gasification was conducted in Wieczorek coal mine of Katowicki Holding Węglowy (KHW) S.A. The process was conducted in coal seam no. 501, at the depth of $464 \mathrm{~m}$ related to the

Table 1. Main parameters of gasification process and purification system, markings as in Figures 2-6

\begin{tabular}{|c|c|}
\hline Parameter, Unit & Value \\
\hline Seam thickness $\mathrm{H}, \mathrm{m}$ & 5.4 \\
\hline Conditions of seam deposition u & [3] \\
\hline Planned maximum gasification capacity, $\mathrm{kg} / \mathrm{h}$ & 600 \\
\hline Obtained maximum capacity, $\mathrm{kg} / \mathrm{h}$ & 830 \\
\hline Average capacity during exploitation, $\mathrm{kg} / \mathrm{h}$ & 174 \\
\hline Max stream of gasification air from D1, D1R, $\mathrm{m}_{n}{ }_{\mathrm{n}} / \mathrm{h}$ & 1400 \\
\hline Max stream of UCG gas, $\mathrm{m}_{\mathrm{n}}^{3} / \mathrm{h}$ & 1800 \\
\hline Amount of other gasification agents & acc. to Fig. 1 \\
\hline Assumed length of test (ignition, process, extinguishing), day & $\sim 90$ \\
\hline \multirow{7}{*}{$\begin{array}{r}\text { Performance of scrubber SV } \\
\text { Temperature of water in cooling system HE11,HE21,HE22,HE23 } \\
\text { Regulation of reverse adsorbers }\end{array}$} & $\begin{array}{l}\text { Method: } \\
\text { - through stabilizing negative pressure behind georeactor in three control - measure- } \\
\text { ment points selected by the operator (PID). }\end{array}$ \\
\hline & $\begin{array}{l}\text { - through setting threshold value of air stream or through content of oxidant in gasi- } \\
\text { fication agent }\end{array}$ \\
\hline & $\begin{array}{l}\text { - (PI) for HE01 regulation of the input value through capacity of a gas/air heat ex- } \\
\text { changer, other ones }(\mathrm{HE} 11, \mathrm{HE} 21, \mathrm{HE} 22, \mathrm{HE} 23) \text { calibrated through initial setting of the } \\
\text { flow of water. }\end{array}$ \\
\hline & - periodical, stream of water adjusted with manually operated valves \\
\hline & - filling the system, 3-position control. \\
\hline & $\begin{array}{l}\text { - setting reverse, exchange of sorbent basing on data from the system monitoring gas } \\
\text { composition. }\end{array}$ \\
\hline & $\begin{array}{l}\text { - setting the valve for gases supplied from tanks of } \mathrm{N}_{2}, \mathrm{O}_{2}, \mathrm{CO}_{2} \text {, setting inverter for } \\
\text { gases supplied with blowers D1,D1R. In case of emergency for D1, D1R throttle/re- } \\
\text { lease PID control }\end{array}$ \\
\hline $\begin{array}{l}\text { Minimal acceptable temperature of process gas in the under- } \\
\text { ground part (sump), }{ }^{\circ} \mathrm{C}\end{array}$ & 70 \\
\hline Range of calorific value of raw gas, $\mathrm{MJ} / \mathrm{m}_{\mathrm{n}}^{3}$ & $3.2-:-4.7$ \\
\hline
\end{tabular}


Cooling water $11 \mathrm{Mg} / \mathrm{h}$ max. (optional)

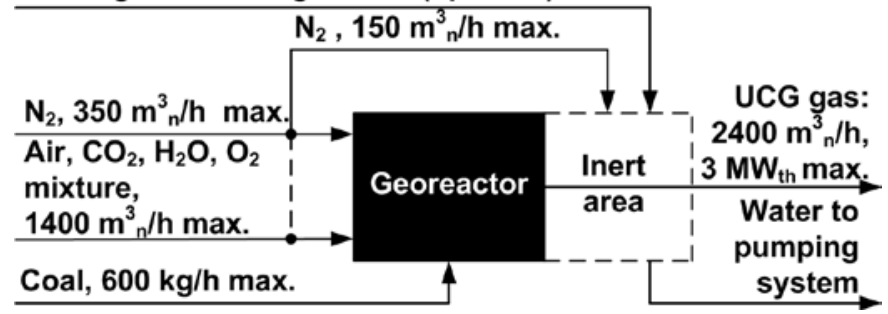

Fig. 1. Balance assumptions of underground gasification

ground surface elevation. The method of locating a georeactor in the rock mass was described in [10], while in [13] and [14] there are details concerning UCG installation design before modifications. Main assumptions of UCG are contained in Table 1. In Figure 1, which is a simplified balance diagram of the georeactor, there are assumed substance streams. Spatial configuration of the georeactor is presented in Figure 2. DN150 pipeline transported a gasification agent. DN100 pipeline served as a spare pipeline and back-up supply of inert gas into the georeactor and exhaust of excess liquid products from the cavity. DN300 pipeline exhausted process products from the georeactor.

\section{Conducting the process}

The rules which govern coal mines in Poland are described in documents required by the legal regulations [16]. Supervising authorities voiced no formal objections concerning the procedures of controlling the installation and assumptions associated with its safety during the tests. The gasification process was directly controlled from a control room in the surface section of the installation. Multipoint measurements of air composition and monitoring it in the workings surrounding the gasified coal seam was realized with Zefir mine system [5]. Communication between mine monitoring system and the UCG supervising system enabled taking decisions in operator mode.

\section{Limitations considered during design and construc- tion stages}

Limitations, apart from the ones resulting from assumptions of running the process, (Table 1.) were as follows:

- approximately $42 \mathrm{~m}$ of the process gas pipeline under water,

- the pipeline in the vicinity of coal seams [3]. It was associated with the risk of heating and, as a consequence, igniting the coal seam. That is why temperature of the pipeline should not exceed $40{ }^{\circ} \mathrm{C}$,

- maximum acceptable concentration of carbon oxide in the underground part could not exceed 26 ppm vol.,

- mining operations in the vicinity of the installation,

- pumps exhausting condensate could not be used in the underground part,

- underground part of the UCG installation was to be maintenance-free.

The above mentioned limiting parameters were determined mainly by operating in conditions of the coal mine. To protect coal seams in the vicinity of the pipeline against heat the whole length of DN300 pipeline was insulated. It prevented part of tar compounds and water

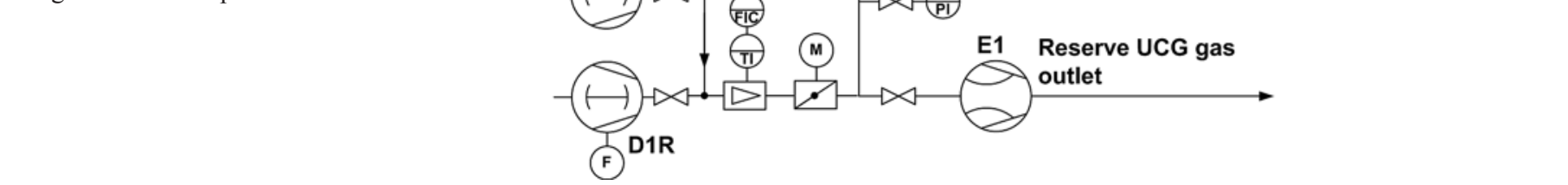

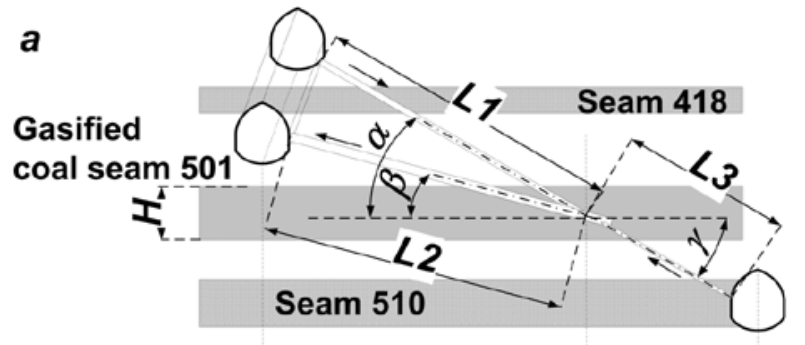

b

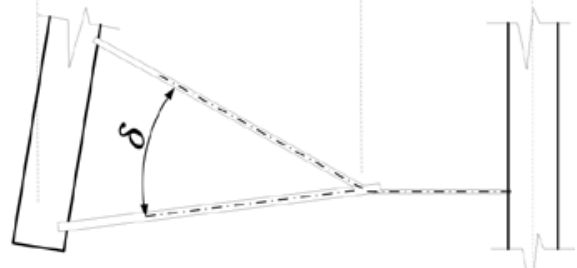

Fig. 3. Diagram of installation dosing gasification agents

from condensing. It enabled exhausting condensate to the surface part of the installation to a place dedicated for the purpose. The effect of using insulation was an increase in thermal stresses in the process gas production pipeline. Expansion joints were used to reduce the thermal stress. Distribution of temperature in DN300 pipeline during the experiment was determined basing on analytical methods [15].

\section{Description of gasification process}

The process part of the gasification installation worked under SCADA system, which was based on ASKOM software [28]. The measurement control system of gasification process and gas purification was based on data from 68 sensors located in crucial points of the installation. Figure 3 presents feeding gasification agents located in the surface section. In figures measurement points of main elements are presented too.

Fig. 2. Spatial configuration of georeactor: a. side view. b. top view 


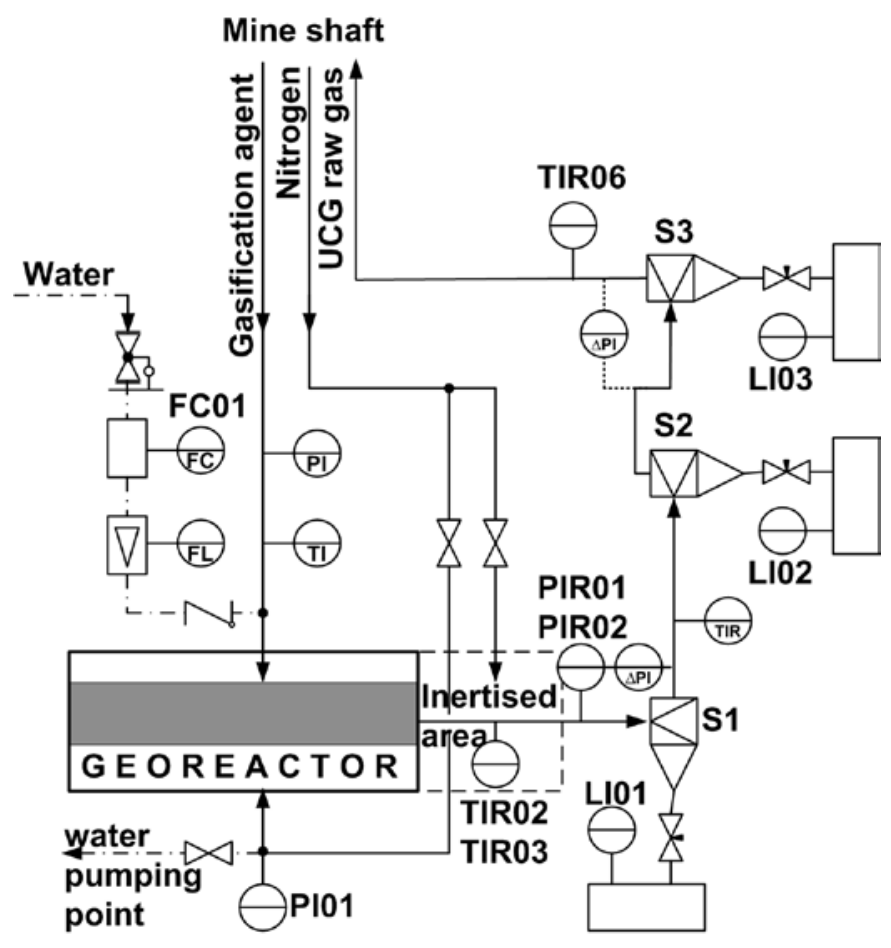

Fig. 4. Underground section of gasification installation. - gas, - - - - water

Nitrogen was injected with DN100 pipeline into the cavity, and into a section of a research gallery behind a stopping. It was possible to connect the pipeline with DN150 gasification agent pipeline, where oxygen was mixed with air from oil-free blowers D1/D1R. The streams of substrates were controlled: with valves - for oxygen, carbon dioxide, nitrogen and air; and with an inverter for air. Ejector E1 played a role of a pressure regulator in the underground installation if the gas production pipeline was cut-off (blocking, caving in the cavity). Then it was possible to exhaust gas and lower the pressure. The ejector was fed with nitrogen, or air, depending on the potential explosion hazard, which was marked basing on chromatographic measurements of UCG gas composition. Part of nitrogen was also used to blow sections of purification system and to feed blowers of a dust monitor (the elements are not marked in the figures).
The process diagram of underground part of the installation is presented in Figure 4, where the crucial parameters applied in the controlling process are presented: pressure before (PI01) and behind the georeactor (PIR01, PIR02) and temperature of raw gas (TIR02, TIR03). Sensors PIR02 TIR03 were kept in reserve. The level of condensate in expansion tanks of separators $\mathrm{S} 1, \mathrm{~S} 2, \mathrm{~S} 3$ was observed with level gauges LI01, LI02, LI03. In separators S1 and S3 decreases in pressure were also measured. Measurements of the decrease enabled checking if the elements of installation are not blocked.

In Figure 4 there are dust and condensate separators S1, S3, S4. While building the installation one of the separators was scrapped (marked as S2), leaving the old markings (S1, S3, S4). A system of feeding process water, which is controlled with FC01 based on measurements of the stream of water, is shown as well. The stream of water feeding the georeactor was measured with flow meter FRC01. Water went into DN150 raw gas pipeline directly before the inlet feeding substrates into the coal seam. UCG gas pipeline together with separators was located in workings which formed part of the existing underground infrastructure and the mine shaft.

Once having left the underground section raw gas was purified. The first stage of the purification system is presented in Figure 5.

Process gas was dedusted in cyclone $\mathrm{C}-1$, then it was initially cooled in heat exchanger HE01 with air fed with fans W11 or W12. Capacity of the fans was controlled with an inverter PI. The value controlled during initial cooling of the gas was its temperature measured with sensor TIC022 behind heat exchanger HE01. Then the gas went through scrubber Venturi SV and the main tar separator HE11. Condenser HE11 and other heat exchangers except HE01 were cooled with treated water.

Coolant was regenerated in a fan cooler. Water circulation systems are not described in the article. At the final stage of gas purification (Fig. 6) water cooled HE21, HE22, HE23 and a gasodynamic, centrifugal tar separator were used. Condensate was collected in a heated collector. Then it was pumped into pallet tanks (IBC). Condensate was exhausted with membrane pumps PM1 and PM2. Gas was purified of acidic compounds in activated carbon adsorbers F01/ F02. Adsorbent regeneration in adsorbers was conducted reversely with air supplied with fan W-13 heated to a given temperature with heater N1. Purified gas was taken through hydraulic back-pressure valve to the flare, where it was combusted.

Monitoring the workings around the georeactor is not the subject of the article. The issue was arranged with Zefir system of the mine, which was supplemented with additional sensors of concentrations of: hydrogen, carbon and methane; and temperature sensors and anemometric flow meters for ventilating air.

\section{Experiences of installation perform- ance}

Pressure within the installation was distributed in a specific way. Before the georeactor there was slightly high pressure, behind it there was negative pressure. Increase in volumetric flow of gas caused by contraction and conversion of coal within the deposit and an increase in temperature led to an increase in resistance of flow. When the difference in pressure between a measuring point in the georeactor and the surrounding workings measured with sensor PI01 exceeded $2000 \mathrm{~Pa}$ there was a risk that gases would infiltrate into the surrounding of the georeactor through the geological structure (workings and ventilation system). The observation was a result of measurements of concentration of hydrogen and carbon oxide in monitoring wells drilled around the gasification zone. Risk of gas outflow into ventilation

Fig. 5. First stage of gas purification system: cyclone C1, initial cooler HE01, scrubber SV, main cooler HE11.—gas, - - - condensate, dust, - - - water 


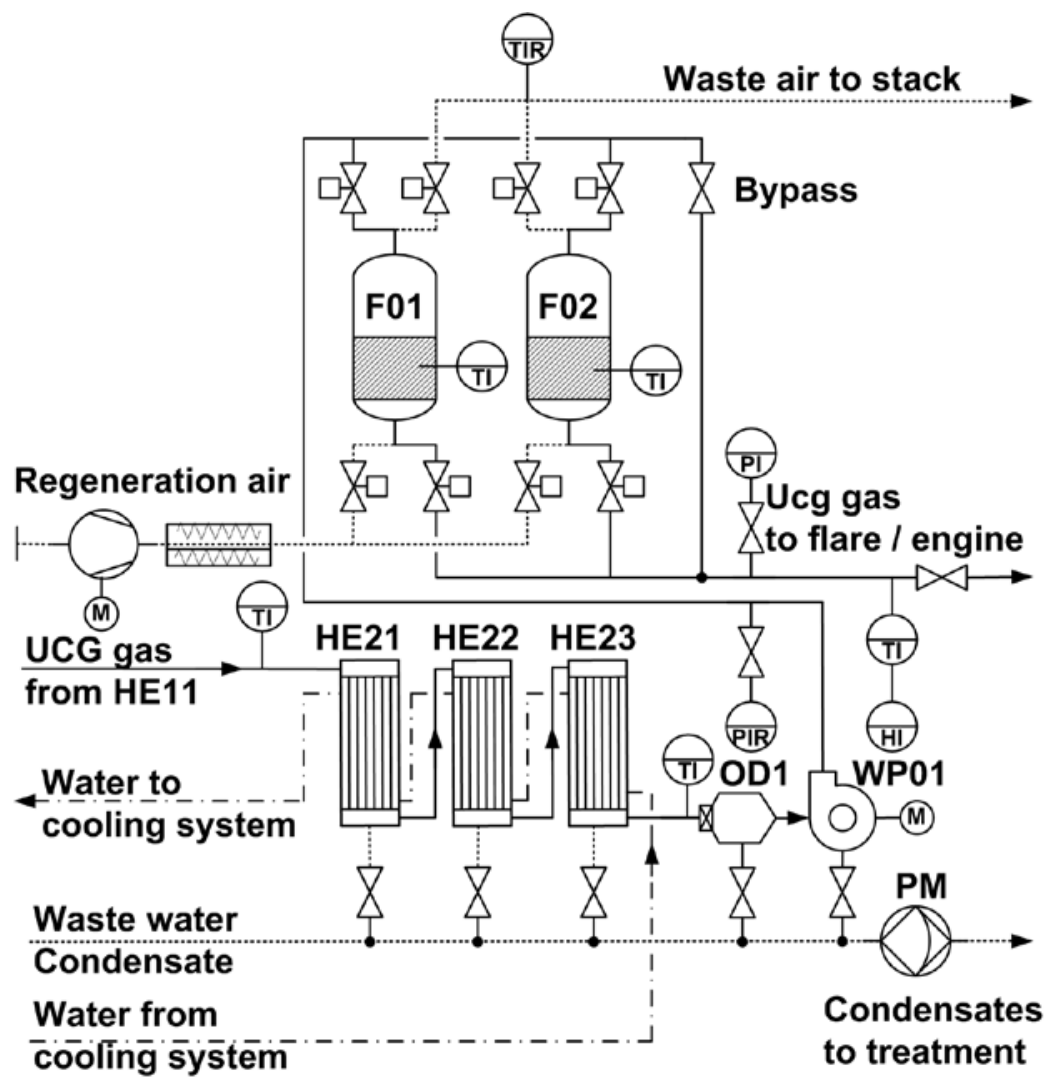

Fig. 6. Third stage of gas purification system. — gas, - - - condensate, air, dust, _ - water

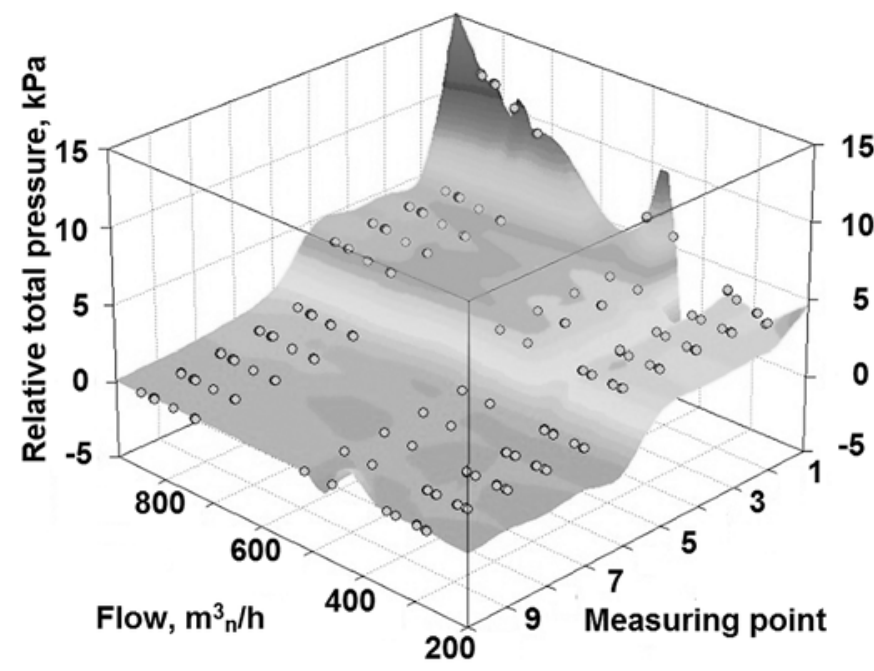

Fig. 7. Flow characteristics of the installation "cold performance". Markings of measuring points: 1. Behind blower D1; 2. Before georeactor; 3. Behind georeactor; 4. Behind separator S1; 5. Behind separator S3; 6. Before cyclone C1; 7. Behind HE01; 8. Behind HE11; 9. Behind cooling system; 10. Before flare

air made it necessary to control negative pressure within the georeactor not to exceed the value of negative pressure in the gasification products exhaust pipeline. High pressure measured before georeactor was maintained at the level of approximately $1500 \mathrm{~Pa}$. Negative pressure behind the georeactor was a function of assumed gasification capacity and an analysis of gas composition conducted in the research gallery. Flow characteristics of the installation changed in time, which resulted from changing volume of the cavity and, to some extent, from condensates, dust and soot, depositing in the pipeline. Initial "cold performance" characteristics of the whole installation, determined before ignition, is presented in Figure 7.

It was determined with WP01 off through regulating capacity of the air stream from blower D1 with an inverter. The test was conducted with gas flowing outside the reverse system of adsorbers (bypass in Figure 6).

\subsection{Surface section - feeding gasification agents}

Controlling streams of gas substrates during the experiments worked properly. Problems were associated with stabilizing pressure and a stream of nitrogen supplied to inertise a research gallery. It was an effect of the fact that assembly of regulators in the nitrogen path was not considered. It was a consequence of initial assumptions that the research gallery (Figure 2) would be flooded. During initial tests, due to excessive seepage of water and risk of flooding wells of the georeactor, the method of securing the georeactor against leakages was changed. Instead of flooding it was decided to build a sand stopping in the gallery. Inert atmosphere in the research gallery was maintained by supplying a stream of nitrogen of approximately $35-50 \mathrm{~kg} / \mathrm{h} \mathrm{N}_{2}$.

During the experiment the process gas production pipeline got blocked and ejector E1 was used to release process gases. Jet pump Huragan 80, installed in DN100 pipeline inlet, was used to produce appropriate negative pressure in the installation. Depending on the explosion hazard it was supplied with nitrogen or compressed air from mine ventilation network.

\subsection{Underground part}

In the underground part circuit breakers, some of the underground sensors and UCG installation control system were regularly checked as it is required by mining regulations. During such a check-up personnel did not receive continuous measurement signals for up to two hours the experiment. At the time the installation was manually controlled. Sudden events like caving, which alter flow characteristics, posed a threat to stability of the installation working.

As there were not any pumps for the condensate in separators S1, S2, S3 it was necessary to maintain acceptable temperature of gas in DN300 pipeline (no lower than $70^{\circ} \mathrm{C}$ ) in the sump. Its aim was to prevent excessive condensing and blocking the pipeline. Failing to maintain minimal acceptable values of temperature of gas in the sump caused excessive tar condensation. The phenomenon was caused mainly by an increase in the amount of water flowing into the shaft (e.g. rainfall, leakage in backfill installation).

Another important issue was also drift of pressure meters. As a result the meters had to be checked and calibrated, i.e. the personnel had to inspect the pipeline. Due to the safety rules assumed at the very beginning of the experiment such actions were impossible.

Dosing water for the process was much more difficult because of impurities in water in pipelines. Water in the fire suppression system was taken from a backfill water settling pond. It contained a lot of sand, which resulted in unreliability of the dosing system.

\subsection{Surface part of process gases purification}

Figure 8 presents a photograph of the installation seen from the side of the gas flare. Process gas purification was based on gradual condensation. It required maintaining the right temperature of raw gas exhausted from the shaft and at given cooling stages. The main controlled parameters were decreases in temperature at given stages of cooling and the stream of gas of water feeding the scrubber.

Gas condensation system worked throughout the whole experiment. The desulfurization process of raw gas in a scrubber was periodically examined. During the tests approximately $90 \pm 20 \mathrm{~g}$ water-tar 
condensate per $1 \mathrm{~m}^{3}$ of UCG gas was exhausted. Purification efficiency was approximately $85-92 \%$ for all fractions, depending on the tested configuration of the equipment and the stream of water injected into membrane heat exchangers and scrubber SV. The effect of applying significant negative pressure on process gas in DN300 pipeline before fan WP01, which was done to protect the underground section of the installation, was a difficulty in pumping water-tar condensate. Chemical compounds in the pumped liquid lowered durability of membranes in the applied condensate pumps. It was necessary to replace membrane pumps with more reliable equipment, of higher capacity and better suited to deal with water-tar mixtures.

During the experiment there were also problems with too low temperature of gas at the inlet of the surface module of purification system which led to condensation in points not prepared for it. The problems were solved through periodical increases in the temperature in the heat exchangers over their standard operational temperature.

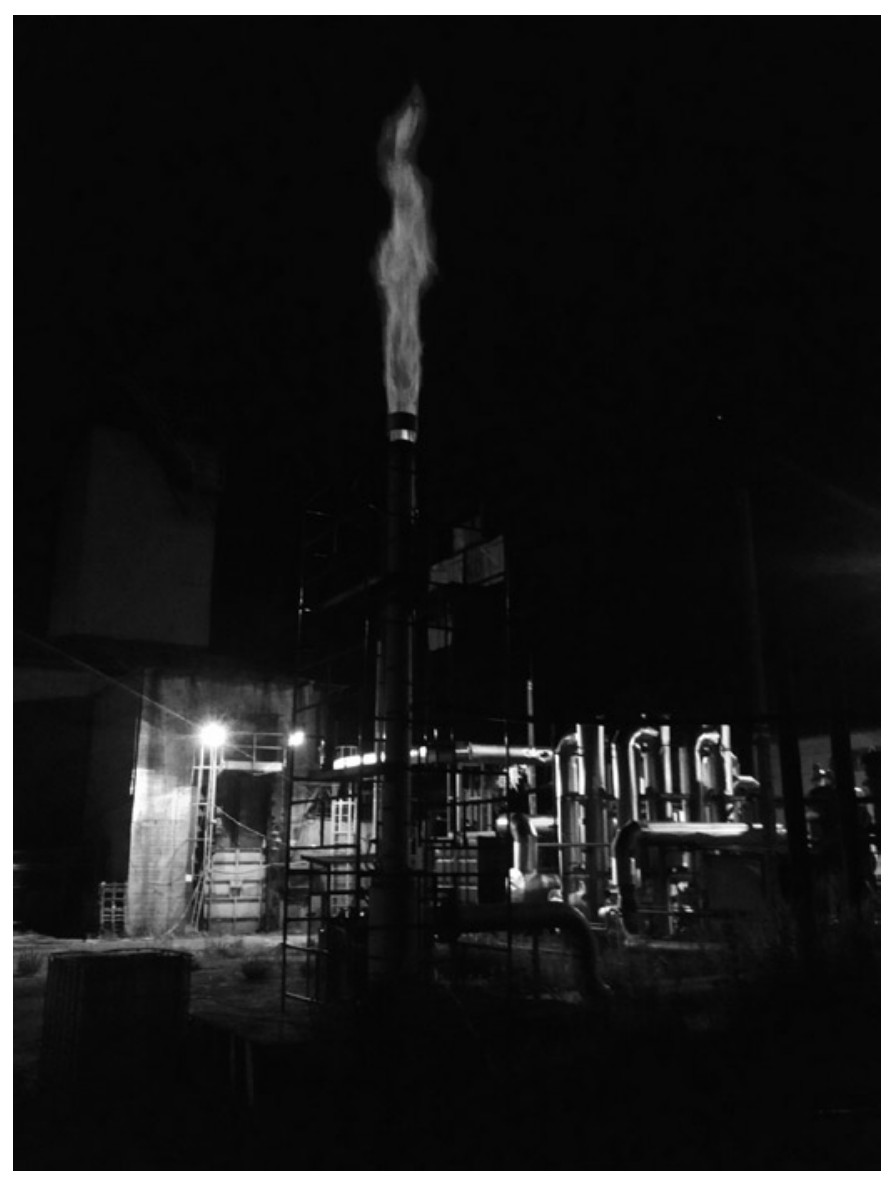

Fig. 8. Flare and part of UCG gas purification system

\section{Stability of the process}

Controlling the UCG process was very stable. The selected measurement ranges in sensors coupled with the control system and applying automatic control of the main parameters worked fine. Increasing volume of the cavity was a factor which stabilised functioning of the installation. That is why given responses to changes in set values and disturbances occurred, as the process progressed, with longer and longer delay.

The most significant disturbance to the process was condensation, which occurred as a result of too low temperature in the sump. There were two main causes of condensation. The first one was the georeactor working at too low parameters. It was a result of the scope of works during the experiment and limitations concerning maximum temperature of $\mathrm{UCG}$ gas at the georeactor outlet $\left(550^{\circ} \mathrm{C}\right.$, whereas, the

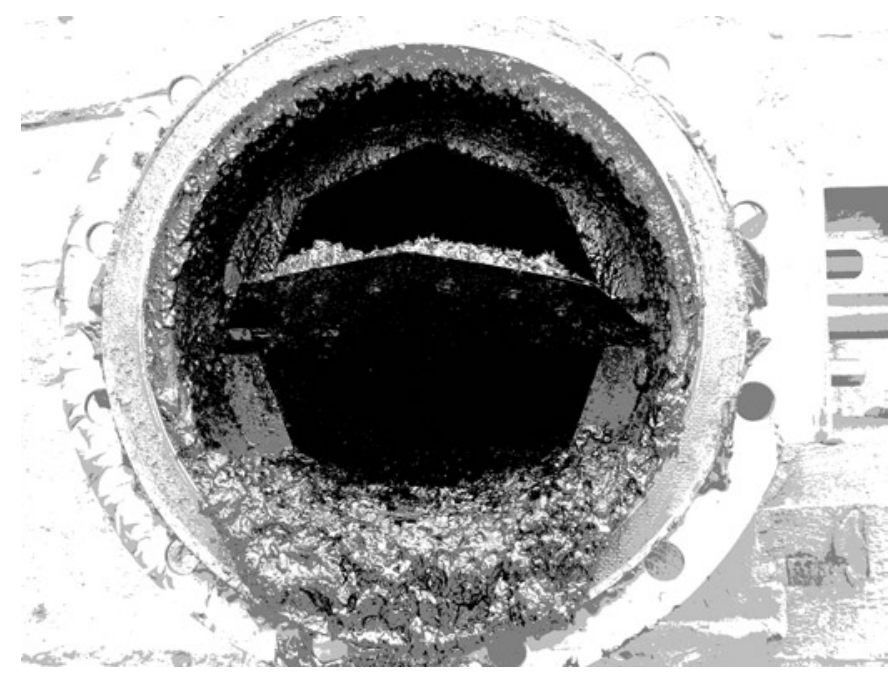

Fig. 9. View of a butterfly valve seat in DN300 raw gas pipeline

maximum computational temperature of long-lasting exploitation was $750^{\circ} \mathrm{C}$ ) imposed by District Mining Office. The other cause was water flowing into the sump of the shaft. The water came from rainfall, leakages in backfill installation and other workings. The flow of water cooled the surface of the insulated pipeline. In practice the first signs of reduced flow in the pipelines were usually observed between 20 and 40 hours before the event. Excessive condensing was avoided through maintaining proper distribution of temperature of gas in the installation and observing decreases in pressure of UCG gas flowing in different sections of the installation.

Figure 9 shows the seat of a butterfly valve installed in DN300 pipeline at the inlet of raw gas into purification system. As it can be seen in the photo significant amount of condensate and dust deposited on protrusions near the valve seat. Near the valve in a smooth pipeline the process did not occur, hence, it is important to insulate heat leakage bridges (flanges, points of mounting support, compensators) properly. In this given case flanges of the pipeline and the valve were such bridges.

Figure 10 presents the changes in temperature in main elements of the installation after initiating gasification process. The initial rapid increase in temperature is an effect of using ignition material and

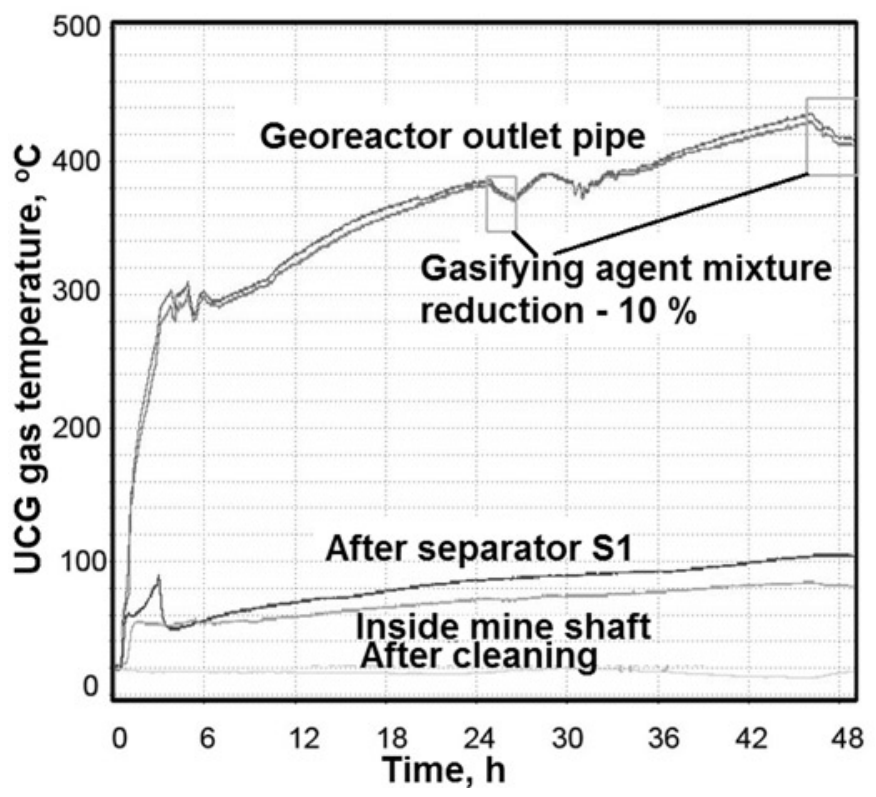

Fig. 10. Distribution of temperature in gasification process in its initial phase for different points of gasification installation 
significant amount of volatile matter formed in the first stage of the process.

\section{Summary}

1. Applying original, integrated design and measurements enabled obtaining a technologically efficient method of producing energy in UCG process.

2. The assumed method of stabilizing low-pressure within the volume of georeactor enabled operating safely in the underground part of installation. Ordinary mining operations were conducted in its vicinity throughout the experiment, and concentrations of toxic components (i.e.: $\mathrm{CH}_{4}, \mathrm{CO}$ i $\mathrm{H}_{2}$ ) did not exceed the threshold limit values.

3. Insulating the production pipeline reduced the amount of substances condensing inside the raw gas pipeline and transferred most of condensation into the surface part of the installation.

4. Efficiency of purifying gas of condensing substances was (except $\mathrm{H} 2 \mathrm{O}$ ) on average $86 \%$ with the scrubber off, and $92 \%$ with the scrubber on.
5. Procedures of operating underground gasification plant were prepared basing on the operational and exploitation data. The procedures can be treated as a standard if the type of industrial processes are implemented.

6. Trace concentration of $\mathrm{O}_{2}$ in process gas while the georeactor was working means the installation is sufficiently leak tight.

7. Tests conducted in laboratory reactors and minimal model installations do not enable obtaining information concerning exploitation and durability of the installation, thermal issues in industrial conditions and events typical for industrial processes. It is necessary to conduct further research into prolonged gasification in mining operations conditions.

This paper is a part of the ongoing Research Task "Development of coal gasification technology for highly efficient production of fuels and energy" funded by the National Centre for Research and Development under the Strategic Programme for Research and Development entitled: 'Advanced energy generation technologies'.

\section{References}

1. Advanced materials modelling and lifting technologies for gas turbine components operating in coal gasification plant. Cleaner Coal Technology Programme Project Profile 287, DTI, Alstom 2001.

2. Bell D A, Towler B F, Fan M. Coal gasification and its applications. New York: Elsevier 2011.

3. Chećko J. Analiza warunków geologiczno - górniczych i hydrogeologicznych w.rejonie projektowanego georeaktora zlokalizowanego w KWK "Wieczorek" (Analysis of geological, mining and hydrogeological conditions in the area of planned georeactor in Wieczorek coal mine). Przegląd Górniczy 2; 2013: 37-45.

4. Couch G. Underground coal gasification. London, United Kingdom: IEA Clean coal Centre. 2009. Report No. CCC 151.

5. Dec B, Gajoch A. System dyspozytorski ZEFIR - struktura programu (Zefir dispatching system). Mechanizacja i Automatyzacja Górnictwa. 2000, 4-5, 108-118.

6. Doctor R D, Molburg J C, Thimmapuram P R. KRW oxygen-blown gasification combined cycle. carbon dioxide recovery, transport and disposal, Raport NETL 1996, http://dx.doi.org/10.2172/373835.

7. Howard J B, ed. Elliot M A. Chemistry of coal utilization. Vol. II. New York: Willey and Sons 1981.

8. Karcz A. Koksownictwo (Coke engineering). P. II. Kraków: Wyd. Akademii Górniczo - Hutniczej, 1991.

9. Kowalski J. Wytwarzanie gazu do syntezy (Producing gas for syntheses). Warszawa: PWT, 1954.

10. Krause E, Lasek S. Wpływ uwarunkowań górniczo - geologicznych oraz wentylacyjnych na projektowaną lokalizację georeaktora oraz bezpieczeństwo procesowe podziemnego zgazowania węgla w czynnej kopalni (Influence of geological, mining and ventilation conditions on planned location of georeactor and safety of underground coal gasification in active coal mine). Przegląd Górniczy, 2013; 2: 46-54.

11. Matuszewski M, Rutkowski R, Schoff R, Comparison of Pratt and Whitney Rocketdyne IGCC and commercial IGCC performance, Raport NETL $2006 \mathrm{r}$.

12. Maurstad O. An overview of coal based integrated gasification combined cycle (IGCC) Technology. MIT Publication no.: MIT LFEE 2005002 WP. 2005.

13. Mocek P, Gil I, Świądrowski J. Instalacja procesowa dla hybrydowej technologii podziemnego zgazowania węgla (Process installation for hybrid technology of underground coal gasification). Przemysł Chemiczny 2014; 1: 66-69.

14. Mocek P, Gil I, Wodołażski A. Wybrane zagadnienia projektowania instalacji oczyszczania produktów podziemnego zgazowania węgla (Selected problems of designing installation to purify underground coal gasification products). Przegląd Górniczy 2013; 2: 99-107.

15. Mocek P, Gil I. Przesył gazu z podziemnego zgazowania węgla (Underground coal gasification gas transmission). Przegląd Górniczy 2013; 2: $107-115$.

16. Prawo geologiczne i górnicze. Ustawa z dnia 9 czerwca 2011 r. Dziennik Ustaw $2011 \mathrm{nr} 163$ poz. 981.

17. Rezaiyan J, Cheremisinoff N P, Gasification technologies. A primer for engineers and scientists. Boca Raton: Taylor \& Francis Group, 2005.

18. Spath P L, Dayton D C. Preliminary Screening - Technical and Economic Assessment of Synthesis Gas to Fuels and Chemicals with Emphasis on the Potential for Biomass-Derived Syngas. Raport NREL/TP-510-34929, 2003.

19. Specification for Fuel Gases for Combustion in Heavy-Duty Gas turbines. Raport GE power Systems Gas Turbine; GEI41040G, 2002.

21. Stańczyk K, Howaniec N, Smoliński A, Świądrowski K, Kapusta K, Wiatowiski M. Gasification of lignite and hard coal with air and oxygen enriched coal in a pilot scale ex situ reactor for underground gasification. Fuel 2011; 5: 1953-1962, http://dx.doi.org/10.1016/j. fuel.2010.12.007.

22. Steinbrecht D, Wolff H J, Matzmohr R, Nassour R, Didk H. Investigations of low calorific landfill gases by a small scale fluidised bubbling bed combustion plant. Global NEST Journal 2007; 9: 42-50.

23. Swan Hills Synfuels. Swan Hills In-situ coal gasification technology development final outcomes report. Alberta Innovates - Energy and Environment Solutions Report 2012.

24. Tampa Electric Polk power station integrated gasification combined cycle project. Raport NETL nr.: DE-FC-21-91MC27363: 2002 r. 
25. Tomeczek J. Zgazowanie Węgla (Coal Gasification). Gliwice: Wyd. Politechniki Śląskiej, 1994.

26. Vulfovich K E. Producton of synthetic hydrocarbons for coal through its underground gasification. International Journal of Mining Science and Technology 2013; 23: 279-285, http://dx.doi.org/10.1016/j.ijmst.2013.04.006.

27. Wiatowski M, Stańczyk K, ŚwiądrowskiJ, Kapusta K, Cybulski K, Krause E, Grabowski J, Rogut J, Howaniec N, Smoliński A. Semitechnical underground coal gasification (UCG) using the shaft method in Experimental Mine "Barbara". Fuel 2012; 99: 170-179, http:// dx.doi.org/10.1016/j.fuel.2012.04.017.

28. Woolcock J, Brown R. A Review of Cleaning Technologies for Biomass-Derived Syngas. Biomass and Bioenergy 2013; 52: 54-84, http:// dx.doi.org/10.1016/j.biombioe.2013.02.036.

29. www.asix.com.pl

30. Yang L, Zhang X, Liu S, Yu L, Zhang W. Field test of large-scale hydrogen manufacturing from underground coal gasification (UCG). International Journal of Hydrogen Energy 2008; 33: 1275-1285, http://dx.doi.org/10.1016/j.ijhydene.2007.12.055.

\section{Piotr MOCEK}

Department of Energy Saving And Air Protection

Central Mining Institute

Plac Gwarków 1, 40-166 Katowice, Poland

\section{Radosław ZAMIAR}

INTROL 4 TECH Sp. z o.o.

16 Lipca 14, 41-506 Chorzów Batory, Poland

\section{Robert JACHIMCZYK}

P.W. „SEMAKO”Sp. z o.o.

Wiejska 40, 44-153 Łany Wielkie k/ Gliwic, Poland

\section{Ryszard GOWARZEWSKI}

Katowicki Holding Węglowy

Wieczorek Coal Mine, Poland

\section{Jerzy ŚWIĄDROWSKI \\ Iwona GIL}

Krzysztof STAŃCZYK

Department of Energy Saving And Air Protection

Central Mining Institute

Plac Gwarków 1, 40-166 Katowice, Poland

Email:pmocek@gig.eu, rzamiar@i4t.com.pl, rjachimczyk@semako.pl, rgowarzewski@khw.pl, jswiadrowski@gig.eu, igil@gig.eu, kstanczyk@gig.eu 